\title{
PENGAMANAN INTELIJEN KEPOLISIAN TERHADAP PUTUSAN PENGADILAN ATAS OBJEK SENGKETA
}

\author{
La Ode Husen ${ }^{1 *}$, Salle Salle², Arri Abdi Syalman ${ }^{3}$, Abd. Kahar Muzakkir ${ }^{4}$ \\ ${ }^{1}$ Guru Besar Fakultas Hukum, Universitas Muslim Indonesia, Makassar \\ ${ }^{2}$ Dosen Fakultas Hukum, Universitas Muslim Indonesia, Makassar \\ ${ }^{3}$ Mahasiswa Program Doktor Ilmu Hukum, Pascasarjana Universitas Muslim Indonesia, Makassar \\ ${ }^{4}$ Editor Penerbit CV. Social Politic Genius (SIGn), Indonesia \\ *Penulis Korespondensi: La Ode Husen \\ Email Korespondensi: laode.husen@umi.ac.id
}

Received: 5 Maret 2020

Accepted: 25 Maret 2020

\begin{abstract}
Abstrak. Penelitian ini bertujuan untuk menganalisis efektivitas pengamanan Intelijen Kepolisian terhadap putusan pengadilan atas objek sengketa di Provinsi Sulawesi Selatan. Penelitian ini menggunakan metode penelitian studi empiris yang biasa pula disebut dengan penelitian hukum sosiologis, karena melihat penerapan hukum sebagai suatu kondisi faktual di lingkungan sosial dan hubungannya terhadap norma hukum. Penelitian ini dilakukan di Provinsi Sulawesi Selatan, dengan jumlah responden sebanyak 92 orang. Analisis data dalam penelitian ini menggunakan pendekatan kualitatif, dimana mengolah output dari kuesioner, dan disajikan dalam bentuk tabulasi frekuensi (F) dan distribusi persentasi (\%). Hasil penelitian menunjukan bahwa pengamanan Ditintelkam Polda Sulawesi Selatan terhadap proses eksekusi atas objek sengketa di Provinsi Sulawesi Selatan berdasarkan Perkap BIN No. 2 Tahun 2013, dapat dinilai dari empat aspek, antara lain: Sasaran Pengamanan; Pelaksanaan Pengamanan; Koordinasi dan Administrasi; serta Pengawasan dan Pengendalian. Perolehan data dari keseluruhan indikator berdasarkan aspek-aspek pengamanan Ditintelkam Polda Sulawesi Selatan menunjukkan hasil yang kurang efektif. Dibutuhkan keseriusan dalam meningkatkan efektivitas pengamanan Ditintelkam Polda Sulawesi Selatan guna memastikan proses eksekusi putusan pengadilan atas objek sengketa bisa lebih efektif di masa akan datang.
\end{abstract}

Kata Kunci:

Ditintelkam Polda; Efektivitas Pengamanan;

Eksekusi Putusan;

Objek Sengketa;

Putusan Pengadilan.

artikel dengan akses terbuka dibawah lisensi CC BY -4.0

\section{PENDAHULUAN}

Ketentuan pembukaan dan batang tubuh Undang-Undang Dasar Negara Republik Indonesia Tahun 1945 menegaskan bahwa Indonesia merupakan negara hukum (rechtsstaat), maka kedudukan hukum harus ditempatkan di atas segala-galanya. ${ }^{1}$ Hukum melingkupi segenap tingkah laku warga negaranya. Lebih lanjut, Negara

${ }^{1}$ La Ode Husen \& Husni Thamrin. (2017). Hukum Konstitusi: Kesepakatan (Agreement) dan Kebiasaan (Custom) Sebagai Pilar Konvensi Ketatanegaraan. Makassar: CV. Social Politic Genius (SIGn), hlm. 13. 
Hukum menghendaki pemerintah untuk melayani kebutuhan mayoritas segenap warga negaranya, tanpa diskriminasi berdasarkan asal usulnya, agamanya, atau strata sosial warga negaranya. ${ }^{2}$

Terwujudnya ketertiban dan keseimbangan dalam kehidupan bermasyarakat merupakan tujuan pokok dari penegakan hukum, sehingga setiap kepentingan warga negara harus dan tetap terlindungi. ${ }^{3}$ Lebih lanjut, terdapat tiga unsur dalam penegakan hukum, antara lain: kepastian hukum, kemanfaatan hukum dan keadilan. ${ }^{4}$ Ketiga unsur tersebut dalam tataran praktiknya diimplementasikan pada putusan pengadilan, salah satunya ialah putusan pengadilan atas objek sengketa. Pada putusan pengadilan melekat kekuatan eksekusi yang merupakan manifestasi dari kekuatan hukum tetap sehingga setiap eksekusi dari putusan pengadilan tidak boleh ditunda. ${ }^{5}$

Pada dasarnya, eksekusi tidak dilakukan apabila pihak yang kalah secara sukarela menerima dan melaksanakan putusan pengadilan. Jika tidak, maka dapat dilakukan eksekusi berupa pelaksanaan putusan secara paksa. ${ }^{6}$ Adapun sumber hukum yang melekat pada kekuatan eksekusi, menurut Djazuli Bachar terdiri dari: ${ }^{7}$

1. Undang-Undang Hukum Acara Perdata;

2. Undang-Undang lain yang berhubungan;

3. Peraturan Mahkamah Agung Republik Indonesia; dan

4. Surat Edaran Mahkamah Agung Republik Indonesia.

Di sisi lain, untuk memastikan proses eksekusi berjalan sebagaimana diharapkan, maka dapat melibatkan pihak kepolisian guna memberikan pengamanan dan perlindungan terhadap para eksekutor putusan pengadilan atas objek sengketa. ${ }^{8} \mathrm{Hal}$ ini sebagaimana berdasarkan Pasal 15 ayat (1) huruf 1 Undang-Undang Republik Indonesia Nomor 2 Tahun 2002 tentang Kepolisian Negara Republik Indonesia (selanjutnya disebut UU No. 2 Tahun 2002) mengatur bahwa:

"Dalam rangka menyelenggarakan tugas ... Kepolisian Negara Republik Indonesia secara umum berwenang memberikan bantuan pengamanan dalam sidang dan pelaksanaan putusan pengadilan, kegiatan instansi lain, serta kegiatan masyarakat."

\footnotetext{
${ }^{2}$ Nurul Qamar, et al. (2018). Negara Hukum atau Negara Kekuasaan (Rechtsstaat or Machtstaat). Makassar: CV. Social Politic Genius (SIGn), hlm. 2.

${ }^{3}$ Laurensius Arliman S. (2019). Mewujudkan Penegakan Hukum yang Baik di Negara Hukum Indonesia. Dialogia Iuridica: Jurnal Hukum Bisnis dan Investasi, Universitas Kristen Maranatha, 11(1), hlm. 12.

${ }^{4}$ Suwardi Sagama. (2016). Analisis Konsep Keadilan, Kepastian Hukum dan Kemanfaatan dalam Pengelolaan Lingkungan. Mazahib: Jurnal Pemikiran Hukum Islam, Institut Agama Islam Negeri Samarinda, 15(1), hlm. 22.

${ }^{5}$ Widhy Andrian Pratama. (2019). Penegakan Hukuman Mati terhadap Pembunuhan Berencana. SIGn Jurnal Hukum, CV. Social Politic Genius (SIGn), 1(1), hlm. 35.

${ }^{6}$ Alfeus Jebabun, et al. (2018). Asesmen Awal Permasalahan Eksekusi Putusan Perkara Perdata di Indonesia. Jakarta: Lembaga Kajian dan Advokasi untuk Independensi Peradilan (LeIP) bekerjasama dengan International Development Law Organization (IDLO), hlm. 9.

${ }^{7}$ Djazuli Bachar. (2008). Eksekusi Putusan Perkara Perdata: Segi Hukum dan Penegakan Hukum. Jakarta: Akademika Pressindo, hlm. 12.

${ }^{8}$ Depri Liber Sonata. (2012). Permasalahan Pelaksanaan Lelang Eksekusi Putusan Pengadilan dalam Perkara Perdata dalam Praktik. Fiat Justisia: Jurnal Ilmu Hukum, Universitas Lampung, 6(2), hlm. 17.
} 
Dari ketentuan di atas, pihak kepolisian dalam memberikan bantuan pengamanan harus melibatkan Badan Intelijen Kepolisian dimana berdasarkan Pasal 3 Undang-Undang Republik Indonesia Nomor 17 Tahun 2011 tentang Intelijen Negara (selanjutnya disebut UU No. 17 Tahun 2011) mengatur bahwa "hakikat Intelijen Negara merupakan lini pertama dalam sistem keamanan nasional".

Lebih lanjut, pengamanan merupakan salah satu tugas intelijen pada lingkup kepolisian, yang dilakukan dengan menerapkan prosedur, metode, teknik, dan taktik, guna menciptakan keamanan dan ketertiban dalam kehidupan berbangsa dan bernegara, ${ }^{9}$ Oleh karena itu, peran Intelijen Kepolisian dalam menjalankan tugasnya termasuk pengamanan terhadap eksekusi objek sengketa dapat menciptakan kondisi keamanan dan ketertiban di lingkungan masyarakat.

Berdasarkan uraian tersebut di atas, maka penelitian ini bertujuan untuk menganalisis efektivitas pengamanan Intelijen Kepolisian terhadap putusan pengadilan atas objek sengketa di Provinsi Sulawesi Selatan. Adapun manfaat dari penelitian tersebut ialah sebagai upaya untuk menemu kenali pola pengamanan dari keterlibatan Intelijen Kepolisian pada saat dilakukan eksekusi objek sengketa, khususnya di Provinsi Sulawesi Selatan.

\section{METODE}

Penelitian ini menggunakan metode penelitian studi empiris yang biasa pula disebut dengan penelitian hukum sosiologis, karena melihat penerapan hukum sebagai suatu kondisi faktual di lingkungan sosial dan hubungannya terhadap norma hukum. ${ }^{10}$ Penelitian ini dilakukan di Provinsi Sulawesi Selatan, dengan jumlah responden sebanyak 92 orang. Lebih lanjut, jenis dan sumber data yaitu terdiri dari data primer dan sekunder, dimana data primer diperoleh langsung di lokasi penelitian melalui proses wawancara, sedangkan data sekunder diperoleh dari hasil kajian dengan menggunakan bahan-bahan pustaka seperti Buku, Artikel Ilmiah, Peraturan Perundang-undangan, dokumen-dokumen resmi serta tulisan-tulisan lain yang mempunyai relevan dengan pembahasan penelitian ini. Analisis data dalam penelitian ini menggunakan pendekatan kualitatif, dimana mengolah output dari kuesioner, dan disajikan dalam bentuk tabulasi frekuensi (F) dan distribusi persentasi (\%).

\section{HASIL DAN PEMBAHASAN}

Eksekusi pada dasarnya memiliki pengertian yang sama dengan menjalankan suatu putusan (ten uitvoer legging van vonnissen), dimana dalam pelaksanaannya dapat dilakukan "secara paksa" dengan bantuan kekuatan umum, bilamana pihak yang

\footnotetext{
${ }^{9}$ Herius Harefa, Fitriati Fitriati, \& Ferdi Ferdi. (2018). Optimalisasi Fungsi Intelijen Kepolisian dalam Penyelidikan Tindak Pidana Narkotika yang Dilakukan Anggota Kepolisian (Studi Sat Intelkam Polres Solok). Unes Law Review, Universitas Ekasakti Padang, 1(1), hlm. 48.

${ }^{10}$ Nurul Qamar, et al. (2017). Metode Penelitian Hukum (Legal Research Methods). Makassar: CV. Social Politic Genius (SIGn), hlm. 52.
} 
kalah tidak mengindahkan putusan pengadilan atas objek sengketa. ${ }^{11}$ Secara umum, pelaksanaan tata tertib beracara terkait eksekusi terhadap putusan pengadilan atas objek sengketa perdata di Indonesia diatur dalam Staatsblad Nomor 44 Tahun 1941 tentang Herzien Inlandsch Reglement (HIR)/Reglemen Indonesia yang Diperbaharui (RIB) (selanjutnya disebut RIB). ${ }^{12}$ Lebih lanjut, cara paksa pada proses eksekusi dimana berdasarkan Pasal 197 ayat (1) RIB mengatur bahwa:

"Jika sudah lewat tempo yang ditentukan itu, dan yang dikalahkan belum juga memenuhi keputusan itu, atau ia jika dipanggil dengan patut, tidak datang menghadap, maka ketua oleh karena jabatannya memberi perintah dengan surat, supaya disita sekalian banyak barang-barang yang tidak tetap dan jika tidak ada, atau ternyata tidak cukup sekian banyak barang tetap kepunyaan orang yang dikalahkan itu sampai dirasa cukup akan pengganti jumlah uang yang tersebut di dalam keputusan itu dan ditambah pula dengan semua biaya untuk menjalankan keputusan itu."

Adapun eksekutor dari putusan pengadilan atas objek sengketa perdata, berdasarkan Pasal 54 ayat (2) Undang-Undang Republik Indonesia Nomor 48 Tahun 2009 tentang Kekuasaan Kehakiman (selanjutnya disebut UU No. 48 Tahun 2009) mengatur bahwa "Pelaksanaan putusan pengadilan dalam perkara perdata dilakukan oleh panitera dan juru sita dipimpin oleh ketua pengadilan".

Apabila dalam proses eksekusi dinilai akan menghadirkan gangguan/kondisi yang tidak aman terhadap objek sengketa, maka eksekutor dapat meminta bantuan kepada pihak kepolisian, ${ }^{13}$ sebagaimana berdasarkan Pasal 197 ayat (9) RIB mengatur bahwa:

"Panitera atau orang yang ditunjuk menggantinya, menurut keadaan, dapat meninggalkan barang-barang yang tidak tetap atau sebagian dari itu dalam persimpanan orang yang barangnya disita itu, atau menyuruh membawa sebagian dari barang itu ke satu tempat persimpanan yang patut. Dalam hal pertama, maka ia memberitahukan kepada polisi desa atau polisi kampung, dan polisi itu harus menjaga, supaya jangan ada dari barang itu dilarikan. Opstal Indonesia tidak dapat dibawa ke tempat lain."

Berdasarkan ketetapan di atas, keterlibatan pihak kepolisian merupakan suatu keharusan, sebagaimana menurut Satjipto Rahardjo bahwa: ${ }^{14}$

"Polisi merupakan alat negara yang bertugas memelihara keamanan dan ketertiban masyarakat, memberikan pengayoman, dan memberikan perlindungan kepada masyarakat."

\footnotetext{
${ }^{11}$ M. Yahya Harahap. (2007). Ruang Lingkup Permasalahan Eksekusi Bidang Perdata. Jakarta: PT. Gramedia Pustaka Utama, hlm 5.

${ }^{12}$ M. Tanziel Aziezi, et al. (2019). Kertas Kebijakan Penguatan Sistem Eksekusi Sengketa Perdata di Indonesia. Jakarta: Lembaga Kajian dan Advokasi untuk Independensi Peradilan (LeIP), hlm. 9; lihat juga Editorial. (2018, 19 April). Eksekusi dalam Teori dan Praktek. Dalam Fakultas Hukum Universitas Indonesia. Diakses pada tanggal 28 Februari 2020.

${ }^{13}$ Tim Penyusun (Ed.) (2019). Pedoman Eksekusi pada Pengadilan Negeri. Jakarta: Direktorat Jenderal Badan Peradilan Umum, Mahkamah Agung RI, hlm. 40. hlm. 111.

${ }^{14}$ Satjipto Rahardjo. (2009). Penegakan Hukum: Suatu Tinjauan Sosiologis. Yogyakarta: Genta Publishing,
} 
Dalam rangka efektifitas tugas kepolisian mengingat Indonesia merupakan negara kepulauan, maka berdasarkan Pasal 6 ayat (2) UU No. 2 Tahun 2002 mengatur bahwa:

"Dalam rangka pelaksanaan peran dan fungsi kepolisian, wilayah negara Republik Indonesia dibagi dalam daerah hukum menurut kepentingan pelaksanaan tugas Kepolisian Negara Republik Indonesia."

Dari ketentuan di atas dan berdasarkan konteks kekinian, maka disahkanlah Peraturan Kepolisian Negara Republik Indonesia Nomor 14 Tahun 2018 tentang Susunan Organisasi dan Tata Kerja Kepolisian Daerah (selanjutnya disebut PerPolri No. 14 Tahun 2018). Lebih lanjut untuk memastikan pemeliharaan keamanan di Daerah, salah satu fungsi berdasarkan Pasal 4 huruf b PerPolri No. 14 Tahun 2018 mengatur bahwa:

"Dalam melaksanakan tugas ..., Polda menyelenggarakan fungsi pelaksanaan intelijen keamanan guna pencegahan gangguan dan pemeliharaan keamanan dalam negeri"

Selanjutnya, berdasarkan Pasal 1 angka 18 PerPolri No. 14 Tahun 2018 menjelaskan bahwa:

"Direktorat Intelijen Keamanan yang selanjutnya disebut Ditintelkam adalah unsur pelaksana tugas pokok dalam bidang intelijen keamanan pada tingkat Polda yang berada di bawah Kapolda"

Dari ketentuan di atas dan untuk memastikan peran pengamanan Intelijen Kepolisian, baik di lingkup Mabes Polri hingga Polda, maka disahkanlah Peraturan Kepala Badan Intelijen Keamanan Kepolisian Negara Republik Indonesia Nomor 2 Tahun 2013 tentang Pengamanan Intelijen Kepolisian Negara Republik Indonesia (selanjutnya disebut Perkap BIN No. 2 Tahun 2013). Perkap BIN No. 2 Tahun 2013 memuat aspek pengamanan intelijen yang terbagi berdasarkan BAB-BAB ketentuan, antara lain:

1. Sasaran Pengamanan;

2. Pelaksanaan Pengamanan;

3. Koordinasi dan Administrasi; serta

4. Pengawasan dan Pengendalian.

Adapun penelitian yang telah dilakukan berkenaan dengan efektivitas pengamanan Ditintelkam Polda Sulawesi Selatan terhadap proses eksekusi atas objek sengketa di Provinsi Sulawesi Selatan berdasarkan Perkap BIN No. 2 Tahun 2013, maka keempat aspek tersebut akan diuraikan satu persatu, antara lain sebagai berikut:

\section{A. Sasaran Pengamanan}

Berdasarkan Pasal 4 Perkap BIN No. 2 Tahun 2013 mengatur bahwa sasaran pengamanan Intelijen Polri meliputi:
a. orang/personel;
b. benda/material/instalasi/tempat/lokasi;
c. kegiatan; dan
d. bahan keterangan/informasi. 
Adapun hasil perolehan data wawancara dengan responden terkait efektivitas berdasarkan aspek sasaran pengamanan Ditintelkam Polda Sulawesi Selatan terhadap proses eksekusi atas objek sengketa di Sulawesi Selatan, dapat dilihat pada tabel berikut ini.

Tabel 1. Efektivitas Pengamanan Ditintelkam Polda Sulawesi Selatan Berdasarkan Aspek Sasaran Pengamanan

\begin{tabular}{c|l|c|c|c|c|c|c|c|c}
\hline \hline \multirow{2}{*}{ No. Indikator } & \multicolumn{2}{|c|}{ Efektif } & \multicolumn{2}{c|}{$\begin{array}{c}\text { Kurang } \\
\text { Efektif }\end{array}$} & \multicolumn{2}{c|}{$\begin{array}{c}\text { Tidak } \\
\text { Efektif }\end{array}$} & \multicolumn{2}{c}{ Total } \\
\cline { 3 - 11 } & & $\mathbf{F}$ & $\mathbf{\%}$ & $\mathbf{F}$ & $\mathbf{\%}$ & $\mathbf{F}$ & $\mathbf{\%}$ & $\mathbf{F}$ & $\mathbf{\%}$ \\
\hline \hline 1. & Orang/Personel & 28 & 30,43 & 47 & 51,09 & 17 & 18,48 & 92 & 100 \\
\hline 2. & $\begin{array}{l}\text { Benda/Material/Instalasi/Tempat/ } \\
\text { Lokasi }\end{array}$ & 19 & 20,65 & 59 & 64,13 & 14 & 15,22 & 92 & 100 \\
\hline 3. & Kegiatan & 28 & 30,44 & 52 & 56,52 & 12 & 13,04 & 92 & 100 \\
\hline 4. & Bahan Keterangan/Informasi & 19 & 20,65 & 57 & 61,96 & 16 & 17,39 & 92 & 100 \\
\hline \hline
\end{tabular}

Sumber: Data Primer Tahun 2020

Dari tabel di atas menunjukkan bahwa indikator no. 1 memperoleh hasil dimana terdapat 28 orang atau 30,43\% menyatakan efektif; 47 orang atau $51,09 \%$ menyatakan kurang efektif; 17 orang atau 18,48\% menyatakan tidak efektif. Indikator no. 2 memperoleh hasil dimana terdapat 19 orang atau $20,65 \%$ menyatakan efektif; 59 orang atau 64,13\% menyatakan kurang efektif; 14 orang atau 15,22\% menyatakan tidak efektif. Indikator no. 3 memperoleh hasil dimana terdapat 28 orang atau 30,44\% menyatakan efektif; 52 orang atau $56,52 \%$ menyatakan kurang efektif; 12 orang atau 13,04\% menyatakan tidak efektif. Indikator no. 4 memperoleh hasil dimana terdapat 19 orang atau 20,65\% menyatakan efektif; 57 orang atau 61,96\% menyatakan kurang efektif; 16 orang atau $17,39 \%$ menyatakan tidak efektif.

Berdasarkan uraian hasil perolehan data di atas, dapat dinilai bahwa efektivitas berdasarkan aspek sasaran pengamanan Ditintelkam Polda Sulawesi Selatan terhadap proses eksekusi atas objek sengketa di Sulawesi Selatan masih kurang efektif.

\section{B. Pelaksanaan Pengamanan}

Pelaksanaan pengamanan terdiri dari tiga tahap dan melingkupi sasaran pengamanan sebagaimana dimaksud pada Pasal 4 Perkap BIN No. 2 Tahun 2013. Selanjutnya, ketentuan pelaksanaan pengamanan berdasarkan Perkap BIN No. 2 Tahun 2013, antara lain sebagai berikut:

1. Pasal 12 ayat (1), mengatur tentang "tahap persiapan pengamanan orang/ personel".

2. Pasal 13 ayat (1), mengatur tentang "tahap pelaksanaan pengamanan orang/ personel".

3. Pasal 14, mengatur tentang "tahap pengakhiran pengamanan orang/personel". 
4. Pasal 15 ayat (1), mengatur tentang "tahap persiapan pengamanan benda/ material/instalasi/tempat/lokasi".

5. Pasal 16 ayat (1), mengatur tentang "tahap pelaksanaan pengamanan benda/ material/instalasi/tempat/lokasi".

6. Pasal 17, mengatur tentang "tahap pengakhiran pengamanan benda/material/ instalasi/tempat/lokasi".

7. Pasal 18 ayat (1), mengatur tentang "tahap persiapan pengamanan kegiatan".

8. Pasal 19 ayat (1), mengatur tentang "tahap pelaksanaan pengamanan kegiatan".

9. Pasal 20, mengatur tentang "tahap pengakhiran pengamanan kegiatan".

10. Pasal 21, mengatur tentang "tahap persiapan pengamanan bahan keterangan/ informasi".

11. Pasal 22, mengatur tentang "tahap pelaksanaan pengamanan bahan keterangan/informasi".

12. Pasal 23, mengatur tentang "tahap pengakhiran pengamanan bahan keterangan/informasi".

Adapun hasil perolehan data wawancara dengan responden terkait efektivitas berdasarkan aspek pelaksanaan pengamanan Ditintelkam Polda Sulawesi Selatan terhadap proses eksekusi atas objek sengketa di Sulawesi Selatan, dapat dilihat pada tabel berikut ini.

Tabel 2. Efektivitas Pengamanan Ditintelkam Polda Sulawesi Selatan Berdasarkan Aspek Pelaksanaan Pengamanan

\begin{tabular}{|c|c|c|c|c|c|c|c|c|c|}
\hline \multirow{2}{*}{ No. } & \multirow{2}{*}{ Indikator } & \multicolumn{2}{|c|}{ Efektif } & \multicolumn{2}{|c|}{$\begin{array}{l}\text { Kurang } \\
\text { Efektif }\end{array}$} & \multicolumn{2}{|c|}{$\begin{array}{l}\text { Tidak } \\
\text { Efektif }\end{array}$} & \multicolumn{2}{|c|}{ Total } \\
\hline & & $\mathbf{F}$ & $\%$ & $\mathbf{F}$ & $\%$ & $\mathbf{F}$ & $\%$ & $\mathbf{F}$ & $\%$ \\
\hline 1. & $\begin{array}{l}\text { Tahap Persiapan Pengamanan Orang/ } \\
\text { Personel }\end{array}$ & 29 & 31,52 & 44 & 47,83 & 19 & 20,65 & 92 & 100 \\
\hline 2. & $\begin{array}{l}\text { Tahap Pelaksanaan Pengamanan } \\
\text { Orang/Personel }\end{array}$ & 28 & 30,43 & 51 & 55,44 & 13 & 14,13 & 92 & 100 \\
\hline 3. & $\begin{array}{l}\text { Tahap Pengakhiran Pengamanan } \\
\text { Orang/Personel }\end{array}$ & 31 & 33,70 & 44 & 47,83 & 17 & 18,47 & 92 & 100 \\
\hline 4. & $\begin{array}{l}\text { Tahap Persiapan Pengamanan Benda/ } \\
\text { Material/Instalasi/Tempat/Lokasi }\end{array}$ & 35 & 38,04 & 43 & 46,74 & 14 & 15,22 & 92 & 100 \\
\hline 5. & $\begin{array}{l}\text { Tahap Pelaksanaan Pengamanan } \\
\text { Benda/Material/Instalasi/Tempat/ } \\
\text { Lokasi }\end{array}$ & 29 & 31,52 & 48 & 52,17 & 15 & 16,31 & 92 & 100 \\
\hline 6. & $\begin{array}{l}\text { Tahap Pengakhiran Pengamanan } \\
\text { Benda/Material/Instalasi/Tempat/ } \\
\text { Lokasi }\end{array}$ & 31 & 33,70 & 45 & 48,91 & 16 & 17,39 & 92 & 100 \\
\hline 7. & $\begin{array}{l}\text { Tahap Persiapan Pengamanan } \\
\text { Kegiatan }\end{array}$ & 25 & 27,17 & 55 & 59,78 & 12 & 13,05 & 92 & 100 \\
\hline 8. & $\begin{array}{l}\text { Tahap Pelaksanaan Pengamanan } \\
\text { Kegiatan }\end{array}$ & 31 & 33,70 & 48 & 52,17 & 13 & 14,13 & 92 & 100 \\
\hline 9. & $\begin{array}{l}\text { Tahap Pengakhiran Pengamanan } \\
\text { Kegiatan }\end{array}$ & 26 & 28,26 & 55 & 59,78 & 11 & 11,96 & 92 & 100 \\
\hline
\end{tabular}




\begin{tabular}{c|l|c|c|c|c|c|c|c|c}
\hline \hline \multirow{2}{*}{ No. } & \multicolumn{2}{|c|}{ Indikator } & \multicolumn{2}{|c|}{ Efektif } & \multicolumn{2}{c|}{$\begin{array}{c}\text { Kurang } \\
\text { Efektif }\end{array}$} & \multicolumn{2}{c|}{$\begin{array}{c}\text { Tidak } \\
\text { Effektif }\end{array}$} & \multicolumn{2}{|c}{ Total } \\
\cline { 3 - 10 } & & $\mathbf{F}$ & $\mathbf{\%}$ & $\mathbf{F}$ & $\mathbf{\%}$ & $\mathbf{F}$ & $\mathbf{\%}$ & $\mathbf{F}$ & $\mathbf{\%}$ \\
\hline \hline 10. & $\begin{array}{l}\text { Tahap Persiapan Pengamanan Bahan } \\
\text { Keterangan/Informasi }\end{array}$ & 31 & 33,69 & 46 & 50,00 & 15 & 16,31 & 92 & 100 \\
\hline 11. & $\begin{array}{l}\text { Tahap Pelaksanaan Pengamanan } \\
\text { Bahan Keterangan/Informasi }\end{array}$ & 18 & 19,56 & 60 & 65,22 & 14 & 15,22 & 92 & 100 \\
\hline 12. & $\begin{array}{l}\text { Tahap Pengakhiran Pengamanan } \\
\text { Bahan Keterangan/Informasi }\end{array}$ & 29 & 31,52 & 45 & 48,91 & 18 & 19,57 & 92 & 100 \\
\hline
\end{tabular}

Sumber: Data Primer Tahun 2020

Dari tabel di atas menunjukkan bahwa indikator no. 1 memperoleh hasil dimana terdapat 29 orang atau 31,52 menyatakan efektif; 44 orang atau 47,83 menyatakan kurang efektif; 19 orang atau 20,65\% menyatakan tidak efektif. Indikator no. 2 memperoleh hasil dimana terdapat 28 orang atau 30,43 menyatakan efektif; 51 orang atau 55,44 menyatakan kurang efektif; 13 orang atau 14,13\% menyatakan tidak efektif. Indikator no. 3 memperoleh hasil dimana terdapat 31 orang atau 33,70 menyatakan efektif; 44 orang atau 47,83 menyatakan kurang efektif; 17 orang atau $18,47 \%$ menyatakan tidak efektif. Indikator no. 4 memperoleh hasil dimana terdapat 35 orang atau 38,04 menyatakan efektif; 43 orang atau 46,74 menyatakan kurang efektif; 14 orang atau 15,22\% menyatakan tidak efektif. Indikator no. 5 memperoleh hasil dimana terdapat 29 orang atau 31,52 menyatakan efektif; 48 orang atau 52,17 menyatakan kurang efektif; 15 orang atau 16,31\% menyatakan tidak efektif. Indikator no. 6 memperoleh hasil dimana terdapat 31 orang atau 33,70 menyatakan efektif; 45 orang atau 48,91 menyatakan kurang efektif; 16 orang atau $17,39 \%$ menyatakan tidak efektif. Indikator no. 7 memperoleh hasil dimana terdapat 25 orang atau 27,17 menyatakan efektif; 55 orang atau 59,78 menyatakan kurang efektif; 12 orang atau 13,05\% menyatakan tidak efektif. Indikator no. 8 memperoleh hasil dimana terdapat 31 orang atau 33,70 menyatakan efektif; 48 orang atau 52,17 menyatakan kurang efektif; 13 orang atau 14,13\% menyatakan tidak efektif. Indikator no. 9 memperoleh hasil dimana terdapat 26 orang atau 28,26 menyatakan efektif; 55 orang atau 59,78 menyatakan kurang efektif; 11 orang atau $11,96 \%$ menyatakan tidak efektif. Indikator no. 10 memperoleh hasil dimana terdapat 31 orang atau 33,69 menyatakan efektif; 46 orang atau 50,00 menyatakan kurang efektif; 15 orang atau 16,31\% menyatakan tidak efektif. Indikator no. 11 memperoleh hasil dimana terdapat 18 orang atau 19,56 menyatakan efektif; 60 orang atau 65,22 menyatakan kurang efektif; 14 orang atau 15,22\% menyatakan tidak efektif. Indikator no. 12 memperoleh hasil dimana terdapat 29 orang atau 31,52 menyatakan efektif; 45 orang atau 48,91 menyatakan kurang efektif; 18 orang atau $19,57 \%$ menyatakan tidak efektif.

Berdasarkan uraian hasil perolehan data di atas, dapat dinilai bahwa efektivitas berdasarkan aspek pelaksanaan pengamanan Ditintelkam Polda Sulawesi Selatan terhadap proses eksekusi atas objek sengketa di Sulawesi Selatan masih kurang efektif. 


\section{Koordinasi dan Administrasi}

Ketentuan koordinasi dan administrasi berdasarkan Perkap BIN No. 2 Tahun 2013, antara lain sebagai berikut:

1. Pasal 24 ayat (1), mengatur tentang "Pelaksana Pengamanan Intelijen yang bersifat terbuka melakukan koordinasi dengan objek/sasaran pengamanan".

2. Pasal 24 ayat (2), mengatur tentang "Pelaksana Pengamanan Intelijen yang bersifat tertutup dilakukan dalam rangka kegiatan kontra intelijen terhadap sasaran".

3. Pasal 25 ayat (1), mengatur tentang "Penyelenggaraan administrasi berpedoman pada administrasi produk Intelijen".

4. Pasal 25 ayat (2), mengatur tentang "Dukungan logistik menggunakan sarana prasarana sesuai kebutuhan".

5. Pasal 25 ayat (3), mengatur tentang "Dukungan anggaran disesuaikan dengan indeks dan kebutuhan kegiatan/Operasi Pengamanan Intelijen".

Adapun hasil perolehan data wawancara dengan responden terkait efektivitas berdasarkan aspek koordinasi dan administrasi Ditintelkam Polda Sulawesi Selatan terhadap proses eksekusi atas objek sengketa di Sulawesi Selatan, dapat dilihat pada tabel berikut ini.

Tabel 3. Efektivitas Pengamanan Ditintelkam Polda Sulawesi Selatan Berdasarkan Aspek Koordinasi dan Administrasi

\begin{tabular}{|c|c|c|c|c|c|c|c|c|c|}
\hline \multirow[t]{2}{*}{ No. } & \multirow[t]{2}{*}{ Indikator } & \multicolumn{2}{|c|}{ Efektif } & \multicolumn{2}{|c|}{$\begin{array}{l}\text { Kurang } \\
\text { Efektif }\end{array}$} & \multicolumn{2}{|c|}{$\begin{array}{l}\text { Tidak } \\
\text { Efektif }\end{array}$} & \multicolumn{2}{|c|}{ Total } \\
\hline & & $\mathbf{F}$ & $\%$ & $\mathbf{F}$ & $\%$ & $\mathbf{F}$ & $\%$ & $\mathbf{F}$ & $\%$ \\
\hline 1. & $\begin{array}{l}\text { Pelaksana Pengamanan Intelijen } \\
\text { yang Bersifat Terbuka Melakukan } \\
\text { Koordinasi dengan Objek/Sasaran } \\
\text { Pengamanan }\end{array}$ & 26 & 28,26 & 51 & 55,44 & 15 & 16,30 & 92 & 100 \\
\hline 2. & $\begin{array}{l}\text { Pelaksana Pengamanan Intelijen yang } \\
\text { Bersifat Tertutup Dilakukan dalam } \\
\text { Rangka Kegiatan Kontra Intelijen } \\
\text { Terhadap Sasaran }\end{array}$ & 26 & 28,26 & 49 & 53,26 & 17 & 18,48 & 92 & 100 \\
\hline 3. & $\begin{array}{l}\text { Penyelenggaraan Administrasi } \\
\text { Berpedoman pada Administrasi } \\
\text { Produk Intelijen }\end{array}$ & 25 & 27,17 & 54 & 58,70 & 13 & 14,13 & 92 & 100 \\
\hline 4. & $\begin{array}{l}\text { Dukungan Logistik Menggunakan } \\
\text { Sarana Prasarana Sesuai Kebutuhan }\end{array}$ & 25 & 27,17 & 55 & 59,78 & 12 & 13,05 & 92 & 100 \\
\hline 5. & $\begin{array}{l}\text { Dukungan Anggaran Disesuaikan } \\
\text { dengan Indeks dan Kebutuhan } \\
\text { Kegiatan/Operasi Pengamanan } \\
\text { Intelijen }\end{array}$ & 31 & 33,70 & 45 & 48,91 & 16 & 17,39 & 92 & 100 \\
\hline
\end{tabular}

Sumber: Data Primer Tahun 2020

Dari tabel di atas menunjukkan bahwa indikator no. 1 memperoleh hasil dimana terdapat 26 orang atau 28,26\% menyatakan efektif; 51 orang atau 55,44\% menyatakan kurang efektif; 15 orang atau 16,30\% menyatakan tidak efektif. Indikator no. 2 memperoleh hasil dimana terdapat 26 orangatau $28,26 \%$ menyatakan 
efektif; 49 orang atau 53,26\% menyatakan kurang efektif; 17 orang atau 18,48\% menyatakan tidak efektif. Indikator no. 3 memperoleh hasil dimana terdapat 25 orang atau $27,17 \%$ menyatakan efektif; 54 orang atau 58,70\% menyatakan kurang efektif; 13 orang atau 14,13\% menyatakan tidak efektif. Indikator no. 4 memperoleh hasil dimana terdapat 25 orang atau 27,17\% menyatakan efektif; 55 orang atau 59,78\% menyatakan kurang efektif; 12 orang atau 13,05\% menyatakan tidak efektif. Indikator no. 5 memperoleh hasil dimana terdapat 31 orang atau 33,70\% menyatakan efektif; 45 orang atau 48,91\% menyatakan kurang efektif; 16 orang atau $17,39 \%$ menyatakan tidak efektif.

Berdasarkan uraian hasil perolehan data di atas, dapat dinilai bahwa efektivitas berdasarkan aspek koordinasi dan administrasi Ditintelkam Polda Sulawesi Selatan terhadap proses eksekusi atas objek sengketa di Sulawesi Selatan masih kurang efektif.

\section{Pengawasan dan Pengendalian}

Berdasarkan Pasal 26 Perkap BIN No. 2 Tahun 2013 mengatur bahwa:

(1) Pengawasan dan pengendalian dalam penyelenggaraan pengamanan intelijen secara struktural dilakukan oleh pejabat Intelkam Polri.

(2) Pengawasan dalam penyelenggaraan pengamanan intelijen secara fungsional dilakukan mulai dari sponsor (SP), Agen Pengendali/Agent Handler (AH), Agen Utama/Principal Agent (PA), Agen Pendukung/Support Agent (SA) dan Agen Pelaksana/Agent Action (AA).

Adapun hasil perolehan data wawancara dengan responden terkait efektivitas berdasarkan aspek pengawasan dan pengendalian Ditintelkam Polda Sulawesi Selatan terhadap proses eksekusi atas objek sengketa di Sulawesi Selatan, dapat dilihat pada tabel berikut ini.

Tabel 4. Efektivitas Pengamanan Ditintelkam Polda Sulawesi Selatan Berdasarkan Aspek Pengawasan dan Pengendalian

\begin{tabular}{|c|c|c|c|c|c|c|c|c|c|}
\hline \multirow{2}{*}{ No. } & \multirow{2}{*}{ Indikator } & \multicolumn{2}{|c|}{ Efektif } & \multicolumn{2}{|c|}{$\begin{array}{l}\text { Kurang } \\
\text { Efektif }\end{array}$} & \multicolumn{2}{|c|}{$\begin{array}{c}\text { Tidak } \\
\text { Efektif }\end{array}$} & \multicolumn{2}{|c|}{ Total } \\
\hline & & $\mathbf{F}$ & $\%$ & $\mathbf{F}$ & $\%$ & $\mathbf{F}$ & $\%$ & $\mathbf{F}$ & $\%$ \\
\hline 1. & $\begin{array}{l}\text { Pengawasan Penyelenggaraan } \\
\text { Pengamanan Intelijen Secara } \\
\text { Struktural }\end{array}$ & 22 & 23,91 & 59 & 64,13 & 11 & 11,96 & 92 & 100 \\
\hline 2. & $\begin{array}{l}\text { Pengendalian Penyelenggaraan } \\
\text { Pengamanan Intelijen Secara } \\
\text { Struktural }\end{array}$ & 26 & 28,26 & 52 & 56,52 & 14 & 15,22 & 92 & 100 \\
\hline 3. & $\begin{array}{l}\text { Pengawasan Penyelenggaraan } \\
\text { Pengamanan Intelijen Secara } \\
\text { Fungsional }\end{array}$ & 19 & 20,65 & 56 & 60,87 & 17 & 18,48 & 92 & 100 \\
\hline 4. & $\begin{array}{l}\text { Pengendalian Penyelenggaraan } \\
\text { Pengamanan Intelijen Secara } \\
\text { Fungsional }\end{array}$ & 28 & 30,44 & 49 & 53,26 & 15 & 16,30 & 92 & 100 \\
\hline
\end{tabular}

Sumber: Data Primer Tahun 2020 
Dari tabel tersebut menunjukkan bahwa indikator no. 1 memperoleh hasil dimana terdapat 22 orang atau 23,91\% menyatakan efektif; 59 orang atau $64,13 \%$ menyatakan kurang efektif; 11 orang atau 11,96\% menyatakan tidak efektif. Indikator no. 2 memperoleh hasil dimana terdapat 26 orang atau 28,26\% menyatakan efektif; 52 orang atau 56,52\% menyatakan kurang efektif; 14 orang atau 15,22\% menyatakan tidak efektif. Indikator no. 3 memperoleh hasil dimana terdapat 19 orang atau 20,65\% menyatakan efektif; 56 orang atau $60,87 \%$ menyatakan kurang efektif; 17 orang atau 18,48\% menyatakan tidak efektif. Indikator no. 4 memperoleh hasil dimana terdapat 28 orang atau 30,44\% menyatakan efektif; 49 orang atau 53,26\% menyatakan kurang efektif; 15 orang atau $16,30 \%$ menyatakan tidak efektif.

Berdasarkan uraian hasil perolehan data di atas, dapat dinilai bahwa efektivitas berdasarkan aspek pengawasan dan pengendalian Ditintelkam Polda Sulawesi Selatan terhadap proses eksekusi atas objek sengketa di Sulawesi Selatan masih kurang efektif.

\section{KESIMPULAN}

Dari uraian hasil dan pembahasan di atas, efektivitas pengamanan Ditintelkam Polda Sulawesi Selatan terhadap proses eksekusi atas objek sengketa di Provinsi Sulawesi Selatan berdasarkan Perkap BIN No. 2 Tahun 2013, dapat dinilai dari empat aspek, antara lain: Sasaran Pengamanan; Pelaksanaan Pengamanan; Koordinasi dan Administrasi; serta Pengawasan dan Pengendalian. Perolehan data dari keseluruhan indikator berdasarkan aspek-aspek pengamanan Ditintelkam Polda Sulawesi Selatan menunjukkan hasil yang kurang efektif. Dibutuhkan keseriusan dalam meningkatkan efektivitas pengamanan Ditintelkam Polda Sulawesi Selatan guna memastikan proses eksekusi putusan pengadilan atas objek sengketa bisa lebih efektif di masa akan datang.

\section{REFERENSI}

Alfeus Jebabun, et al. (2018). Asesmen Awal Permasalahan Eksekusi Putusan Perkara Perdata di Indonesia. Jakarta: Lembaga Kajian dan Advokasi untuk Independensi Peradilan (LeIP) bekerjasama dengan International Development Law Organization (IDLO).

Depri Liber Sonata. (2012). Permasalahan Pelaksanaan Lelang Eksekusi Putusan Pengadilan dalam Perkara Perdata dalam Praktik. Fiat Justisia: Jurnal Ilmu Hukum, Universitas Lampung, 6(2), hlm. 1 - 19. doi: https://doi.org/10.25041/ fiatjustisia.v6no2.329

Djazuli Bachar. (2008). Eksekusi Putusan Perkara Perdata: Segi Hukum dan Penegakan Hukum. Jakarta: Akademika Pressindo.

Editorial. (2018, 19 April). Eksekusi dalam Teori dan Praktek. Dalam Fakultas Hukum Universitas Indonesia. Diakses dari https://law.ui.ac.id/v3/eksekusi-dalamteori-dan-praktek/, pada tanggal 28 Februari 2020. 
Herius Harefa, Fitriati Fitriati, \& Ferdi Ferdi. (2018). Optimalisasi Fungsi Intelijen Kepolisian dalam Penyelidikan Tindak Pidana Narkotika yang Dilakukan Anggota Kepolisian (Studi Sat Intelkam Polres Solok). Unes Law Review, Universitas Ekasakti Padang, 1(1), hlm. 44 - 52. doi: https://doi.org/10.31933/law.v1i1.5

La Ode Husen \& Husni Thamrin. (2017). Hukum Konstitusi: Kesepakatan (Agreement) dan Kebiasaan (Custom) Sebagai Pilar Konvensi Ketatanegaraan. Makassar: CV. Social Politic Genius (SIGn).

Laurensius Arliman S. (2019). Mewujudkan Penegakan Hukum yang Baik di Negara Hukum Indonesia. Dialogia Iuridica: Jurnal Hukum Bisnis dan Investasi, Universitas Kristen Maranatha, 11(1), hlm. 1 - 20. doi: https://doi.org/10.28932/ di.v11i1.1831

M. Tanziel Aziezi, et al. (2019). Kertas Kebijakan Penguatan Sistem Eksekusi Sengketa Perdata di Indonesia. Jakarta: Lembaga Kajian dan Advokasi untuk Independensi Peradilan (LeIP).

M. Yahya Harahap. (2007). Ruang Lingkup Permasalahan Eksekusi Bidang Perdata. Jakarta: PT. Gramedia Pustaka Utama.

Nurul Qamar, et al. (2017). Metode Penelitian Hukum (Legal Research Methods). Makassar: CV. Social Politic Genius (SIGn).

Nurul Qamar, et al. (2018). Negara Hukum atau Negara Kekuasaan (Rechtsstaat or Machtstaat). Makassar: CV. Social Politic Genius (SIGn).

Peraturan Kepala Badan Intelijen Keamanan Kepolisian Negara Republik Indonesia Nomor 2 Tahun 2013 tentang Pengamanan Intelijen Kepolisian Negara Republik Indonesia. Registrasi Setum Polri Nomor 11 Tahun 2013.

Peraturan Kepolisian Negara Republik Indonesia Nomor 14 Tahun 2018 tentang Susunan Organisasi dan Tata Kerja Kepolisian Daerah. Berita Negara Republik Indonesia Tahun 2018 Nomor 1450.

Satjipto Rahardjo. (2009). Penegakan Hukum: Suatu Tinjauan Sosiologis. Yogyakarta: Genta Publishing.

Staatsblad Nomor 44 Tahun 1941 tentang Herzien Inlandsch Reglement (HIR)/ Reglemen Indonesia yang Diperbaharui (RIB).

Suwardi Sagama. (2016). Analisis Konsep Keadilan, Kepastian Hukum dan Kemanfaatan dalam Pengelolaan Lingkungan. Mazahib: Jurnal Pemikiran Hukum Islam, Institut Agama Islam Negeri Samarinda, 15(1), hlm. 20 - 41. doi: https:// doi.org/10.21093/mj.v15i1.590

Tim Penyusun (Ed.) (2019). Pedoman Eksekusi pada Pengadilan Negeri. Jakarta: Direktorat Jenderal Badan Peradilan Umum, Mahkamah Agung RI.

Undang-Undang Dasar Negara Republik Indonesia Tahun 1945.

Undang-Undang Republik Indonesia Nomor 2 Tahun 2002 tentang Kepolisian Negara Republik Indonesia. Lembaran Negara Republik Indonesia Tahun 2002 Nomor 2. Tambahan Lembaran Negara Republik Indonesia Nomor 4168. 
Undang-Undang Republik Indonesia Nomor 48 Tahun 2009 tentang Kekuasaan Kehakiman. Lembaran Negara Republik Indonesia Tahun 2009 Nomor 157. Tambahan Lembaran Negara Republik Indonesia Nomor 5076.

Undang-Undang Republik Indonesia Nomor 17 Tahun 2011 tentang Intelijen Negara. Lembaran Negara Republik Indonesia Tahun 2011 Nomor 105. Tambahan Lembaran Negara Republik Indonesia Nomor 5249.

Widhy Andrian Pratama. (2019). Penegakan Hukuman Mati terhadap Pembunuhan Berencana. SIGn Jurnal Hukum, CV. Social Politic Genius (SIGn), 1(1), hlm. 29 - 41. doi: https://doi.org/10.37276/sjh.v1i1.34

I La Ode Husen, et al. (2020). Efektivitas Pengamanan Intelijen Kepolisian Terhadap 1 I Putusan Pengadilan Atas Objek Sengketa. SIGn Jurnal Hukum, CV. Social Politic Genius ' I (SIGn), 1(2), hlm. 136 - 148. doi: https://doi.org/10.37276/sjh.v1i2.62 